\title{
Genetic mechanisms and age-related macular degeneration: common variants, rare variants, copy number variations, epigenetics, and mitochondrial genetics
}

\author{
Melissa M Liu' ${ }^{1,2}$, Chi-Chao Chan ${ }^{1}$ and Jingsheng Tuo ${ }^{1 *}$
}

\begin{abstract}
Age-related macular degeneration (AMD) is a complex and multifaceted disease involving contributions from both genetic and environmental influences. Previous work exploring the genetic contributions of AMD has implicated numerous genomic regions and a variety of candidate genes as modulators of AMD susceptibility. Nevertheless, much of this work has revolved around single-nucleotide polymorphisms (SNPs), and it is apparent that a significant portion of the heritability of AMD cannot be explained through these mechanisms. In this review, we consider the role of common variants, rare variants, copy number variations, epigenetics, microRNAs, and mitochondrial genetics in AMD. Copy number variations in regulators of complement activation genes (CFHR1 and CFHR3) and glutathione $S$ transferase genes (GSTM1 and GSTT1) have been associated with AMD, and several additional loci have been identified as regions of potential interest but require further evaluation. MicroRNA dysregulation has been linked to the retinal pigment epithelium degeneration in geographic atrophy, ocular neovascularization, and oxidative stress, all of which are hallmarks in the pathogenesis of AMD. Certain mitochondrial DNA haplogroups and SNPs in mitochondrially encoded NADH dehydrogenase genes have also been associated with AMD. The role of these additional mechanisms remains only partly understood, but the importance of their further investigation is clear to elucidate more completely the genetic basis of AMD.
\end{abstract}

Keywords: Age-related macular degeneration, Copy number variation, Genetics, Epigenetics, Mitochondria

Age-related macular degeneration (AMD) is the leading cause of irreversible central vision loss in elderly populations in developed countries, and 30-50 million people are affected worldwide [1]. In the USA, it has been estimated that the prevalence of AMD is $13.4 \%$ in persons aged 60 years and older [2]. AMD primarily affects the photoreceptors, retinal pigment epithelium (RPE), Bruch's membrane, and choriocapillaris in the macula, the part of the retina responsible for central vision. It is classically characterized by the development of drusen, pathological extracellular deposits primarily containing glycolipids, proteins, and cellular debris, between the RPE and Bruch's membrane [3]. Small hard drusen can

\footnotetext{
*Correspondence: tuoj@nei.nih.gov

'Laboratory of Immunology, National Eye Institute, National Institutes of Health, 10/10 N103, 10 Center Dr., Bethesda, MD 20892-1857, USA Full list of author information is available at the end of the article
}

develop with normal aging. Early AMD occurs with more numerous and larger soft drusen in the macula, pigmentary changes in the RPE, and thickening of Bruch's membrane. Advanced AMD can manifest as either geographic atrophy (dry) or neovascular/exudative (wet) AMD. Geographic atrophy, or atrophy of the RPE, and degeneration of the overlying photoreceptors occurs in dry AMD. Wet AMD is characterized by the presence of choroidal neovascularization, leading to fluid leakage, hemorrhage, and disciform scar formation [4].

AMD is a complex and multifaceted disease involving contributions from both genetic and environmental influences. Epidemiological studies have identified age, gender, race, cigarette smoking, diet, and various cardiovascular risk factors as potential modulators of AMD risk, though age and cigarette smoking have been linked most consistently [5]. Numerous genomic regions and a

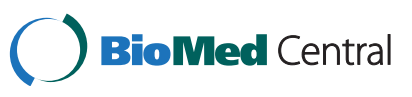


variety of candidate genes have also been shown to impact AMD susceptibility. Although strong associations with AMD have been discovered, it is apparent that a significant portion of the heritability of AMD cannot be explained through these known mechanisms. In a recent meta-analysis of genome-wide association studies (GWAS) for advanced AMD, it was estimated that currently identified loci account for approximately 55\% of the heritability of advanced AMD [6]. There is indeed a need to explore additional factors to elucidate the remaining genetic contributions to AMD susceptibility. In this review, we consider the role of common variants, rare variants, copy number variations, epigenetics, microRNAs, and mitochondrial genetics in AMD.

\section{Common variants}

Linkage and association studies have implicated genetic modulators of AMD risk related to many mechanistic pathways, including oxidative stress, complement system dysregulation, DNA repair, mitochondrial dysfunction, neovascularization, and microglial recruitment [7]. Products of the complement system are present in drusen, and genetic variations in a number of complement components, including $\mathrm{C} 2, \mathrm{C} 3$, complement factor $\mathrm{H}(\mathrm{CFH})$, factor B, and factor I, have been linked to AMD [8]. Much of this work has revolved around single-nucleotide polymorphisms (SNPs). The role of SNPs in AMD has been extensively reviewed [9-12]. The $\mathrm{Y} 402 \mathrm{H}$ polymorphism in $\mathrm{CFH}$ has been consistently demonstrated as a significant risk factor for AMD [13-15], and it has been estimated that the population attributable risk is between $47 \%$ and $69 \%$ [16]. SNPs in genes encoding other inflammatory markers such as CX3CR1 [17] have also been associated with AMD. These findings support a central role for complement activation and inflammation in AMD pathogenesis. SNPs in age-related maculopathy susceptibility 2 (ARMS2) [18-20] and HtrA serine peptidase 1 (HTRA1) $[21,22]$, two genes in strong linkage disequilibrium on chromosome 10q26 related to extracellular matrix function, are also associated with AMD susceptibility. Apoliproprotein $\mathrm{E}$ (apoE) polymorphisms modulate AMD risk as well, with the $\varepsilon 4$ allelic variant conferring protection against $\mathrm{AMD}$ and the $\varepsilon 2$ allelic variant increasing AMD risk [23]. Although controversial, AMD-associated SNPs have also been identified in excision repair crosscomplementing group 6 (ERCC6), a DNA repair gene [24]; serpin peptidase inhibitor, clade G (C1 inhibitor), member 1 (SERPING1), an inhibitor of the complement component C1 [25]; and toll-like receptor 3 (TLR3) [26] and toll-like receptor 4 (TLR4) [27], mediators of the innate immune response.

Several recent GWAS studies have discovered novel AMD susceptibility loci. In a British population, the TNXB-FKBPL-NOTCH4 region was identified [28]. The
TNFRSF10A-LOC389641 and REST-C4orf14-POLR2BIGFBP7 loci have also been identified as susceptibility loci for neovascular AMD in a Japanese population [29]. Variants in SKIV2L, which functions in exosomemediated RNA degradation, and MYRIP, which plays a role in melanosome trafficking in the RPE, have been associated with AMD [30]. SNPs in the FRK/COL10A1 locus, which encodes the type $\mathrm{X}$ collagen alpha chain, and vascular endothelial growth factor A (VEGFA), a key regulator of neovascularization [31], have been associated with AMD as well [6], reiterating the role of extracellular matrix dysfunction and aberrant angiogenesis in AMD pathogenesis. A SNP in tissue inhibitor of metalloproteinases 3 (TIMP3), an inhibitor of extracellular matrix degradation, has been associated with AMD [32]. Hepatic lipase gene (LIPC) [33], cholesterylester transfer protein $(C E T P)$, lipoprotein lipase $(L P L)$, and ATP-binding cassette, sub-family A, member 1 ( $A B C A 1)$, all of which are associated with high-density lipoprotein metabolism, were also identified in this same GWAS study, suggesting that lipid and cholesterol dysregulation may be relevant in AMD as well.

\section{Rare variants}

The concept that rare variants may contribute to the heritability of common diseases is well established. In 2010, a simulation by Sobrin et al. [34] demonstrated that common SNPs are insufficient to account for the AMD burden in densely affected families and that rare penetrant mutations may play a more important role. Several rare variants contributing to AMD risk have been identified. The rare $\mathrm{H} 5 \mathrm{CFH}$ haplotype, which includes a missense mutation leading to a R1210C substitution and functionally deficient $\mathrm{CFH}$, has been identified as a causative variant in certain AMD patients [35]. This example demonstrates that both common and rare mutations in the same gene may modulate AMD risk. Missense mutations in the FIBULIN-5 gene have also been found in $1.7 \%$ of patients in an American AMD population [36]. Rare variants in HEMICENTIN-1 (FIBULIN-6), which encodes an extracellular matrix protein, have also been associated with AMD [37].

\section{Copy number variation}

Copy number variation (CNV) is a common genetic structural variation that contributes greatly to human genetic diversity. $\mathrm{CNVs}$ are defined as deletions and duplications of genomic DNA segments that are at least one kilobase long [38]. Thousands of CNV loci have been identified throughout the human genome [39]. Several mechanisms have been proposed for the origination of $\mathrm{CNV}$, including nonallelic homologous recombination, nonhomologous end-joining, and fork stalling and template switching [40]. The genomic rearrangements 
responsible for $\mathrm{CNVs}$ can lead to pathogenic phenotypes by modulating gene dosage, interrupting a gene, creating a fusion gene, exerting position effects, or unmasking a deleterious recessive mutation [41]. In fact, CNVs in specific genes have been linked to a variety of diseases, including Parkinson's disease, HIV infection, psoriasis, systemic lupus erythematosus, and a variety of neuropsychiatric diseases [42-46]. Nevertheless, the role of CNV in AMD remains incompletely understood.

It has been reported that deletions in $\mathrm{CFH}$-related proteins 1 and 3 (CFHR1 and CFHR3) are protective against AMD. CFH and CFHR1-5, regulators of complement activation, are located in a common locus in linkage disequilibrium on the long arm of chromosome 1 . Hageman et al. identified a large deletion spanning CFHR1 and CFHR3 and demonstrated that homozygosity for this deletion conferred a protective effect, which was particularly evident for advanced AMD [47]. Hughes et al. identified this same deletion in two independent cohorts and demonstrated that its protective effects could not be attributed to the CFH $\mathrm{Y} 402 \mathrm{H}$ genotype [48]. It was later demonstrated that its effects are also independent of the risk-modulating SNP in the $\mathrm{CFH}$ promoter region [49]. A previously characterized $\mathrm{CFH}$ haplotype, which is protective against AMD, occurs frequently in homozygotes for the CFHR1 and CFHR3 deletion. This copy number polymorphism may indeed be responsible for at least part of the protection conferred by the haplotype [50]. Schmid-Kubista et al. characterized CNV in CFHR1 and CFHR3 in 252 AMD patients and 249 controls using multiplex ligation-dependent probe amplification, which allows for quantitative determination of gene copy number [51]. This study reported novel CNVs in this locus, including homozygous deletions of only CFHR 1 or only CFHR 3 , heterozygous deletion of CFHR3 only, and duplication of CFHR1 only. Homozygous deletion of both genes decreased the odds of AMD substantially, and the protective effects of these CNVs were statistically significant for early AMD and neovascular AMD. The effects of heterozygous deletion did not achieve statistical significance, but a trend suggested a gene dosage effect. It was recently estimated that having fewer than two copies of CFHR1 and CFHR3 reduced the odds of having AMD by 43\% [52]. CFHR1 and CFHR3 are regulators of the complement system that inhibit C5 convertase and C3 convertase, respectively. They are also competitive inhibitors of $\mathrm{CFH}$ and interrupt the binding of $\mathrm{CFH}$ to $\mathrm{C} 3$ [49]. A recent report suggests that the protection conferred by deletion of CFHR1 and CFHR3 may not be independent of rs1329428 and rs203687, two SNPs downstream of CFH $\mathrm{Y} 402 \mathrm{H}$ in a novel 32-kb region associated with AMD risk [53]. This study also showed that a different deletion $\mathrm{CNV}$ in a 122-kb region encompassing CFHR1 and
CFHR4 was associated with protection against AMD, independently of other CFH SNPs. The demonstrated role of CNVs and SNPs in modulating the activity of genes in the regulator of complement activation locus further highlights the mechanistic importance of the complement system in AMD pathogenesis.

CNVs in the glutathione $\mathrm{S}$ transferase (GST) genes are common in human populations, and their role in a variety of diseases has been investigated. GSTs are phase II enzymes that defend against oxidative stress and detoxify a variety of electrophilic compounds by covalent conjugation with glutathione [54]. Homozygous deletion of GSTM1 and GSTT1 occurs in approximately 50\% and $20 \%$ of Caucasian individuals, respectively [55]. A decrease in GSTT1 copy number has been linked with cortical cataract [56], and deletions of GSTM1 and GSTT1 are associated with asthma [57]. Preliminary investigations have been performed to evaluate the potential role of GST CNV in AMD. In a study by $\mathrm{Oz}$ et al., copy number genotyping was performed for GSTM1, GSTT1, and GSTP1 in 35 patients with neovascular AMD and 159 controls, and no statistically significant associations were observed between GSTM1, GSTT1, or GSTP1 individually and AMD [58]. However, homozygous deletions for GSTM1/GSTT1 and GSTM1/GSTP1 in combination were both found to significantly increase AMD risk. Guven et al. evaluated GSTM1 and GSTT1 CNV in 120 AMD patients and 198 controls in a Turkish population [59]. Homozygous deletion of GSTM1 was found to be associated with AMD, and the association persisted for dry AMD after stratification by AMD subtype. Statistically significant associations were not observed between GSTM1 or GSTT1 genotype and neovascular AMD. A study by Kimura et al. in a Japanese population also reported no significant association between $\mathrm{CNV}$ in GSTM1 or GSTT1 and neovascular AMD [60].

The potential role for CNV in AMD has been evaluated for a number of other genes. A recent genome-wide scan for CNVs was performed using the Affymetrix GeneChip SNP Microarray in 400 AMD patients and 500 elderly controls. Nephrocystin 1 (NPHP1) and EGF containing fibulin-like extracellular matrix protein (EFEMP1) were identified as genes of interest [61]. Mutations in the NPHP1 gene have been reported in Senior-Loken syndrome, which occurs with Leber congenital amaurosis, in Joubert syndrome, which may cause retinal dystrophy, and also in juvenile nephronophthisis in isolation. A deletion on chromosome $2 \mathrm{q} 13$ containing NPHP1, which functions in signal transduction and cytoskeleton organization, was observed in AMD patients, but not in controls. Duplication of a region upstream of EFEMP1, a gene that is mutated in Doyne honeycomb retinal dystrophy, was also observed in AMD patients, but not in controls. The reported 
CNVs were quite rare, and their mechanistic implications in the context of AMD remain entirely unknown and require further investigation.

We also recently evaluated the potential role of $\mathrm{CNV}$ in neovascular AMD for several candidate genes, including CCR3, CFH, CX3CR1, ERCC6, HTRA1, VEGF, GSTM1, and GSTT1 [62]. Quantitative copy number genotyping was performed for each gene in 131 neovascular AMD patients and 103 elderly controls. Previously unreported CNVs were discovered in CCR3, CX3CR1, and ERCC6, but after adjustment for age, no statistically significant associations were found between CNVs in any of the evaluated genes and AMD. A trend in the unadjusted data suggested that an increase in CX3CR1 copy number might be protective against AMD. This finding complements previously reported studies characterizing the association between two loss-of-function SNPs in CX3CR1, V249I and T280M [17], and elevated AMD risk. Additionally, histological studies have demonstrated that macular CX3CR1 protein levels are decreased in patients with AMD [63]. Further evaluation of the role of CNV in AMD is warranted to better understand the contribution of this type of genetic variation to AMD risk and pathogenesis.

\section{Epigenetics}

Epigenetic modifications, or covalent modifications of genomic DNA that affect gene expression while preserving the DNA sequence, have also been investigated as potential genetic modulators of human disease. Methylation at the $\mathrm{C} 5$ position of cytosine is a common epigenetic modification that decreases gene transcription, and cytosine methylation in CpG dinucleotides can occur in clusters throughout the genome known as $\mathrm{CpG}$ islands. Covalent histone modifications, including methylation, acetylation, sumoylation, and phosphorylation, are also epigenetic modulators that affect gene transcription. Aberrant methylation patterns are associated with genomic instability and recognized as early genetic changes in certain tumors [64]. Loss of imprinting, or the epigenetic modifications that are inherited from parental chromosomes, has also been implicated in several conditions, including Beckwith-Wiedemann syndrome and Prader-Willi syndrome, and DNA methylation defects in T cells may contribute to systemic lupus erythematosus [65]. In experimental models, epigenetic patterns have also been shown to change with parental or embryonic exposure to dietary and environmental factors [66]. Global levels of genomic DNA methylation also decrease with age [67].

Based on these findings, epigenetic modifications may indeed serve as a genetic mechanism by which aging and environmental exposures modulate disease risk. These effects may be particularly pronounced in complex diseases of aging with demonstrated environmental contributions, such as AMD. The study of the role of epigenetics in AMD pathogenesis has only recently begun. A DNA methylation analysis was recently performed in three pairs of monozygotic twins with disparate AMD phenotypes to scan for genome-wide differences in methylation patterns. There were 256 genes with hypomethylated CpG sites and 744 genes with hypermethylated CpG sites in the twins with AMD (L Wei, unpublished work). The authors recently identified the $I L-17 R C$ promoter, which is hypomethylated in AMD patients, as a locus of interest. Hypomethylation at this locus results in elevated expression levels of IL-17 RC in the peripheral blood cells and macular lesions of AMD patients (L Wei, unpublished work). The mechanistic implications of these differences require further investigation.

It is clear that environmental and dietary factors have a significant impact on AMD risk and progression. The Age-Related Eye Disease Study (AREDS) demonstrated that dietary supplements containing antioxidants such as zinc, beta-carotene, vitamin $\mathrm{C}$, and vitamin $\mathrm{E}$ helped to decrease the risk of progression from intermediate to advanced AMD by $25 \%$ over 5 years [68]. Preliminary studies evaluating lutein, zeaxanthin, omega-3 fatty acids, and B vitamins have suggested that these compounds may confer protective effects as well [69]. A case series of monozygotic twin pairs with disparate AMD phenotypes has also been reviewed to assess the impact of behavioral and nutritional factors on AMD [70]. Twins with more advanced AMD tended to be heavier smokers and consumed less dietary vitamin D, betaine, and methionine. The modulatory effects of smoking and antioxidant supplementation on AMD confirm the critical role of oxidative stress in AMD pathogenesis. Additional studies are needed to investigate whether DNA methylation changes or other epigenetic modifications play a contributory role as well, but chronic low levels of antioxidant micronutrients may lead to changes in DNA methylation, synthesis, and repair.

\section{MicroRNAs}

MicroRNAs are 19-25-nucleotide single-stranded noncoding RNAs that post-transcriptionally downregulate gene expression by binding the $3^{\prime}$ untranslated region ( $3^{\prime}$-UTR) of target mRNAs and marking them for cleavage by the RNA-induced silencing complex. MicroRNA genes are transcribed and trimmed to form premicroRNAs with characteristic hairpin structures. PremicroRNAs are cleaved by Drosha, exported from the nucleus, and processed again by Dicer in the cytoplasm to yield mature microRNAs [71]. It has been predicted that $30 \%$ of human genes may be regulated by microRNAs [72]. The role of microRNAs has been demonstrated in several contexts, including cancer [73] and immune function [74], and it is being investigated in AMD as well [75]. 
A recent study has shown that the NF- $\kappa$ B-regulated microRNAs miR-9, miR-125b, miR-146a, and miR-155 are upregulated in both AMD and Alzheimer's disease and that miR-146a and miR-155 target the 3'-UTR of $\mathrm{CFH}$, thereby downregulating $\mathrm{CFH}$ [76]. A reduction in the Dicer1 enzyme and concomitant rise in Alu RNA has also been linked to the RPE degeneration in AMD patients with geographic atrophy [77]. Some studies have investigated the role of microRNAs in ocular neovascularization. It has been shown that microRNAs miR-31, miR-150, and miR-184 are significantly reduced in an ischemia-induced mouse model of retinal neovascularization and in a laser-induced mouse model of choroidal neovascularization in the absence of ischemia [78]. Intraocular injection with pre-miR-31 or pre-miR-150 significantly reduced the size of choroidal neovascular lesions. A recent study also demonstrated that knockdown of miR-23 and miR-27, which downregulate the antiangiogenic factors Sprouty 2 and Sema6A, is protective against laser-induced choroidal neovascularization [79]. MicroRNA23a has also been found to be decreased in RPE cells from AMD donor eyes, and in ARPE-19 cells, it has been shown that antisense-mediated inhibition of miR-23a reduced cell growth and that the addition of a miR-23a mimic reduced $\mathrm{H}_{2} \mathrm{O}_{2}$-induced oxidative damage and Fas-mediated apoptosis [80]. As choroidal neovascularization and oxidative stress are hallmarks in AMD, these microRNAs may provide insights for the development of novel therapeutics.

\section{Mitochondrial genetics}

Cells have several defense mechanisms against oxidative stress, including antioxidant compounds and enzymes and DNA repair machinery, but tissue damage can occur when these mechanisms are overwhelmed, and oxidative stress is believed to be a significant mechanistic contributor in AMD [81]. The retina is particularly susceptible to oxidative damage because it is among the most metabolically active tissues by weight in the body and because it is constantly under photochemical stress. Photoreceptors contain abundant mitochondria and produce high concentrations of reactive oxygen species (ROS) that when inadequately controlled lead to tissue damage, particularly in the underlying RPE. ROS can cause damage to macromolecules and organelles throughout the cell, but oxidative stress-induced mitochondrial DNA (mtDNA) damage has been especially studied as a pathogenic mechanism in AMD $[82,83]$.

There are several factors that contribute to this phenomenon, including the localization of cell respiration reactions and ROS production in the mitochondria and decreased mtDNA repair mechanisms relative to nuclear DNA (nDNA) repair mechanisms, though some mtDNA damage can be corrected via base excision repair and mismatch repair [84]. The accumulation of mtDNA defects leads to an overall decline in mitochondrial function over time. In rodent RPE and choroid, the levels of the oxidative DNA damage marker 8-hydroxy-2'-deoxy-guanosine (8-OHdG) and the levels of deleted mtDNA increased with age, while the levels of certain DNA repair enzymes correspondingly decrease with age [85]. As a consequence of decreased mtDNA repair capacity, oxidative stress has been shown to preferentially damage mtDNA over nDNA in human RPE cells [86]. Accumulation of mtDNA deletions and cytochrome c oxidase deficiency has also been demonstrated with aging in human cone photoreceptors, particularly in the fovea [87]. The number of mtDNA rearrangements and deletions is also greater for the retina than for peripheral blood cells, in both AMD patients and age-matched normal controls [88], supporting the importance of the metabolically active retinal microenvironment and oxidative stress in mtDNA changes. In AMD retinas, mtDNA lesions are increased throughout the mitochondrial genome, and the degree of damage exceeds that which is seen in mtDNA with normal aging [89].

To more specifically characterize the mtDNA changes in AMD, several studies have compared mtDNA variations between AMD patients and normal controls. Jones et al. used restriction fragment length polymorphism analysis to determine mtDNA haplogroups for 3,302 Australian individuals from the Blue Mountains Eye Study, 317 of whom had either early or late AMD [90]. After adjusting for age, sex, and smoking status, mtDNA haplogroup $\mathrm{H}$, the most prevalent haplogroup for European populations, was found to be protective against AMD, especially early AMD, and large soft drusen. Conversely, mtDNA haplogroup $U$ was associated with increased RPE abnormalities. Udar et al. analyzed retinal mtDNA from the eyes of 11 AMD patients and 10 elderly controls and showed that AMD mtDNA had higher levels of oxidative damage, as evidenced by 8 -OHdG staining, and a higher frequency of SNPs [91]. SNPs in the noncoding mtDNA control region at $\mathrm{T} 16126 \mathrm{C}$, T16126C + G13368A, A4917G + A73G, and T3197C+ A12308G were strongly associated with AMD, and these SNPs correlated with mtDNA haplogroups J, T, and U. The A4917G SNP in the mitochondrially encoded NADH dehydrogenase gene, which defines mtDNA haplogroup T, was also shown in separate studies to be associated with increased risk of AMD, potentially by disrupting cell respiration and increasing the production of ROS [92,93]. Carrying the A11812G and A4917G SNPs, both of which lie in NADH ubiquinone oxidoreductase genes, has been associated with a 2.5-fold elevated risk of developing advanced AMD [93]. 


\section{Conclusions}

AMD is a significant cause of irreversible blindness in the elderly, and the global burden of this disease is evergrowing as populations age. The genetic basis of this disease is only partially understood. However, it is hoped that further investigations may lead to the identification of novel therapeutic pathways. Technological advancements have facilitated the exploration of mitochondrial genetics, epigenetic modifications, and genetic structural variations such as CNV in not only AMD but also a variety of other common diseases. The role of $\mathrm{CNV}$ in AMD has thus far proven to be moderate, but the evidence suggests that further studies are warranted. The preliminary experiments evaluating epigenetic modifications in AMD require replication in independent study populations, and additionally, given the demonstrated importance of the retinal microenvironment in AMD, it may be illustrative to evaluate these types of genetic modifications in retinal tissues, not only in peripheral blood mononuclear cells. There is a wide array of heterogeneity in AMD phenotype and response to therapy, and a more complete understanding of the genetics of AMD is critical. Many SNPs have been reproducibly demonstrated in AMD risk and pathogenesis, but there are clearly additional genetic mechanisms that remain to be identified. Common variants explain approximately $55 \%$ of the heritability of AMD. Mechanisms such as rare variants, copy number variations, epigenetics, and mitochondrial inheritance may contribute to the missing heritability. Considering more fully the predisposing genetic factors in AMD may ultimately help to identify high risk populations, predict disease progression, and anticipate response to personalized therapy.

\section{Competing interests}

The authors declare that they have no competing interests.

\section{Authors' contributions}

MML drafted the manuscript. CCC provided critical review. JT determined the scope and focus of the manuscript and participated in its design and review. All authors read and approved the final manuscript.

\section{Author details}

'Laboratory of Immunology, National Eye Institute, National Institutes of Health, 10/10 N103, 10 Center Dr., Bethesda, MD 20892-1857, USA. Johns Hopkins University School of Medicine, Baltimore, MD 21205-2196, USA.

Received: 18 May 2012 Accepted: 21 August 2012

Published: 31 August 2012

\section{References}

1. Gehrs KM, Anderson DH, Johnson LV, Hageman GS: Age-related macular degeneration-emerging pathogenetic and therapeutic concepts. Ann Med 2006, 38:450-471.

2. Klein R, Chou CF, Klein BE, Zhang X, Meuer SM, Saaddine JB: Prevalence of age-related macular degeneration in the US population. Arch Ophthalmol 2011, 129:75-80

3. Hageman GS, Luthert PJ, Chong VNH, Johnson LV, Anderson DH, Mullins RF: An integrated hypothesis that considers drusen as biomarkers of immune-mediated processes at the RPE-Bruch's membrane interface in aging and age-related macular degeneration. Prog Retin Eye Res 2001, 20:705-732

4. Green WR: Histopathology of age-related macular degeneration. Mol Vis 1999, 5:27

5. Coleman HR, Chan CC, Ferris FL 3rd, Chew EY: Age-related macular degeneration. Lancet 2008, 372:1835-1845.

6. Yu Y, Bhangale TR, Fagerness J, Ripke S, Thorleifsson G, Tan PL, Souied EH, Richardson AJ, Merriam JE, Buitendijk GH, Reynolds R, Raychaudhuri S, Chin KA, Sobrin L, Evangelou E, Lee PH, Lee AY, Leveziel N, Zack DJ, Campochiaro B, Campochiaro P, Smith RT, Barile GR, Guymer RH, Hogg R, Chakravarthy U, Robman LD, Gustafsson O, Sigurdsson H, Ortmann W, et al: Common variants near FRK/COL10A1 and VEGFA are associated with advanced age-related macular degeneration. Hum Mol Genet 2011, 20:3699-3709.

7. Ding X, Patel M, Chan CC: Molecular pathology of age-related macular degeneration. Prog Retin Eye Res 2009, 28:1-18.

8. Zipfel PF, Lauer N, Skerka C: The role of complement in AMD. Adv Exp Med Biol 2010, 703:9-24.

9. Deangelis MM, Silveira AC, Carr EA, Kim IK: Genetics of age-related macular degeneration: current concepts future directions. Semin Ophthalmo/ 2011, 26:77-93.

10. Katta S, Kaur I, Chakrabarti S: The molecular genetic basis of age-related macular degeneration: an overview. J Genet 2009, 88:425-449.

11. Patel N, Adewoyin T, Chong NV: Age-related macular degeneration: a perspective on genetic studies. Eye (Lond) 2008, 22:768-776.

12. Swaroop A, Branham KE, Chen W, Abecasis G: Genetic susceptibility to age-related macular degeneration: a paradigm for dissecting complex disease traits. Hum Mol Genet 2007, 16(2):R174-R182.

13. Klein RJ, Zeiss C, Chew EY, Tsai JY, Sackler RS, Haynes C, Henning AK, SanGiovanni JP, Mane SM, Mayne ST, Bracken MB, Ferris FL, Ott J, Barnstable C, Hoh J: Complement factor $\mathrm{H}$ polymorphism in age-related macular degeneration. Science 2005, 308:385-389.

14. Edwards AO, Ritter R 3rd, Abel KJ, Manning A, Panhuysen C, Farrer LA: Complement factor $\mathrm{H}$ polymorphism and age-related macular degeneration. Science 2005, 308:421-424.

15. Haines $J$, Hauser MA, Schmidt S, Scott WK, Olson LM, Gallins P, Spencer KL, Kwan SY, Noureddine M, Gilbert JR, Schnetz-Boutaud N, Agarwal A, Postel EA, Pericak-Vance MA: Complement factor $\mathrm{H}$ variant increases the risk of age-related macular degeneration. Science 2005, 308:419-421.

16. Baird PN, Islam FM, Richardson AJ, Cain M, Hunt N, Guymer R: Analysis of the $\mathrm{Y} 402 \mathrm{H}$ variant of the complement factor $\mathrm{H}$ gene in age-related macular degeneration. Invest Ophthalmol Vis Sci 2006, 47:4194-4198.

17. Tuo J, Smith BC, Bojanowski CM, Meleth AD, Gery I, Csaky KG, Chew EY, Chan CC: The involvement of sequence variation and expression of CX3CR1 in the pathogenesis of age-related macular degeneration. FASEB J 2004, 18:1297-1299.

18. Fritsche LG, Loenhardt $T$, Janssen A, Fisher SA, Rivera A, Keilhauer CN, Weber $\mathrm{BH}$ : Age-related macular degeneration is associated with an unstable ARMS2 (LOC387715) mRNA. Nat Genet 2008, 40:892-896.

19. Kortvely E, Hauck SM, Duetsch G, Gloeckner CJ, Kremmer E, Alge-Priglinger CS, Deeg CA, Ueffing M: ARMS2 is a constituent of the extracellular matrix providing a link between familial and sporadic age-related macular degenerations. Invest Ophthalmol Vis Sci 2010, 51:79-88.

20. Ross RJ, Bojanowski CM, Wang JJ, Chew EY, Rochtchina E, Ferris FL 3rd Mitchell P, Chan CC, Tuo J: The LOC387715 polymorphism and agerelated macular degeneration: replication in three case-control samples. Invest Ophthalmol Vis Sci 2007, 48:1128-1132.

21. Deangelis MM, Ji F, Adams S, Morrison MA, Harring AJ, Sweeney MO, Capone A Jr, Miller JW, Dryja TP, Ott J, Kim IK, Kim IK: Alleles in the HtrA serine peptidase $1 \mathrm{gene}$ alter the risk of neovascular age-related macular degeneration. Ophthalmology 2008, 115:1209-1215.

22. Dewan A, Liu M, Hartman S, Zhang SS, Liu DT, Zhao C, Tam PO, Chan WM, Lam DS, Snyder M, Barnstable C, Pang CP, Hoh J: HTRA1 promoter polymorphism in wet age-related macular degeneration. Science 2006, 314:989-992.

23. Baird PN, Guida E, Chu DT, Vu HT, Guymer RH: The epsilon2 and epsilon4 alleles of the apolipoprotein gene are associated with age-related macular degeneration. Invest Ophthalmol Vis Sci 2004, 45:1311-1315

24. Tuo J, Ning B, Bojanowski CM, Lin ZN, Ross RJ, Reed GF, Shen D, Jiao X, Zhou $M$, Chew EY, Kadlubar FF, Chan CC: Synergic effect of polymorphisms in 
ERCC6 5 ' flanking region and complement factor $\mathrm{H}$ on age-related macular degeneration predisposition. Proc Natl Acad Sci U S A 2006, 103:9256-9261.

25. Ennis S, Jomary C, Mullins R, Cree A, Chen X, Macleod A, Jones S, Collins A, Stone E, Lotery A: Association between the SERPING1 gene and agerelated macular degeneration: a two-stage case-control study. Lancet 2008, 372:1828-1834.

26. Yang Z, Stratton C, Francis PJ, Kleinman ME, Tan PL, Gibbs D, Tong Z, Chen $H$, Constantine R, Yang X, Chen Y, Zeng J, Davey L, Ma X, Hau VS, Wang C, Harmon J, Buehler J, Pearson E, Patel S, Kaminoh Y, Watkins S, Luo L, Zabriskie NA, Bernstein PS, Cho W, Schwager A, Hinton DR, Klein ML, Hamon SC, et al: Toll-like receptor 3 and geographic atrophy in agerelated macular degeneration. N Engl J Med 2008, 359:1456-1463.

27. Zareparsi S, Buraczynska M, Branham KE, Shah S, Eng D, Li M, Pawar H, Yashar BM, Moroi SE, Lichter PR, Petty HR, Richards JE, Abecasis GR, Elner VM, Swaroop A: Toll-like receptor 4 variant D299G is associated with susceptibility to age-related macular degeneration. Hum Mol Genet 2005, $14: 1449-1455$

28. Cipriani V, Leung HT, Plagnol V, Bunce C, Khan JC, Shahid H, Moore AT, Harding SP, Bishop PN, Hayward C, Campbell S, Armbrecht AM, Dhillon B, Deary IJ, Campbell H, Dunlop M, Dominiczak AF, Mann SS, Jenkins SA, Webster AR, Bird AC, Lathrop M, Zelenika D, Souied EH, Sahel JA, Leveillard T, Cree AJ, Gibson J, Ennis S, Lotery AJ, et al: Genome-wide association study of age-related macular degeneration identifies associated variants in the TNXB-FKBPL-NOTCH4 region of chromosome 6p21.3. Hum Mol Genet. in press.

29. Arakawa S, Takahashi A, Ashikawa K, Hosono N, Aoi T, Yasuda M, Oshima Y, Yoshida S, Enaida H, Tsuchihashi T, Mori K, Honda S, Negi A, Arakawa A, Kadonosono K, Kiyohara Y, Kamatani N, Nakamura Y, Ishibashi T, Kubo M: Genome-wide association study identifies two susceptibility loci for exudative age-related macular degeneration in the Japanese population. Nat Genet 2011, 43:1001-1004.

30. Kopplin L, Igo RP Jr, Wang Y, Sivakumaran TA, Hagstrom SA, Peachey NS, Francis PJ, Klein ML, SanGiovanni JP, Chew EY, Pauer GJ, Sturgill GM, Joshi T, Tian L, Xi Q, Henning AK, Lee KE, Klein R, Klein BE, lyengar SK: Genomewide association identifies SKIV2L and MYRIP as protective factors for age-related macular degeneration. Genes Immun 2010, 11:609-621.

31. Dvorak HF, Brown LF, Detmar M, Dvorak AM: Vascular permeability factor/ vascular endothelial growth factor, microvascular hyperpermeability, and angiogenesis. Am J Pathol 1995, 146:1029-1039.

32. Chen W, Stambolian D, Edwards AO, Branham KE, Othman M, Jakobsdottir J, Tosakulwong N, Pericak-Vance MA, Campochiaro PA, Klein ML, Tan PL, Conley YP, Kanda A, Kopplin L, Li Y, Augustaitis KJ, Karoukis AJ, Scott WK, Agarwal A, Kovach JL, Schwartz SG, Postel EA, Brooks M, Baratz KH, Brown WL, Brucker AJ, Orlin A, Brown G, Ho A, Regillo C, et al: Genetic variants near TIMP3 and high-density lipoprotein-associated loci influence susceptibility to agerelated macular degeneration. Proc Natl Acad Sci U S A 2010, 107:7401-7406.

33. Neale BM, Fagerness J, Reynolds R, Sobrin L, Parker M, Raychaudhuri S, Tan PL, Oh EC, Merriam JE, Souied E, Bernstein PS, Li B, Frederick JM, Zhang K, Brantley MA Jr, Lee AY, Zack DJ, Campochiaro B, Campochiaro P, Ripke S, Smith RT, Barile GR, Katsanis N, Allikmets R, Daly MJ, Seddon JM: Genomewide association study of advanced age-related macular degeneration identifies a role of the hepatic lipase gene (LIPC). Proc Natl Acad Sci U S A 2010, 107:7395-7400.

34. Sobrin L, Maller JB, Neale BM, Reynolds RC, Fagerness JA, Daly MJ, Seddon $J \mathrm{M}$ : Genetic profile for five common variants associated with age-related macular degeneration in densely affected families: a novel analytic approach. Eur I Hum Genet 2010, 18:496-501.

35. Raychaudhuri S, lartchouk O, Chin K, Tan PL, Tai AK, Ripke S, Gowrisankar S, Vemuri S, Montgomery K, Yu Y, Reynolds R, Zack DJ, Campochiaro B, Campochiaro P, Katsanis N, Daly MJ, Seddon JM: A rare penetrant mutation in CFH confers high risk of age-related macular degeneration. Nat Genet 2011, 43:1232-1236.

36. Stone EM, Braun TA, Russell SR, Kuehn MH, Lotery AJ, Moore PA, Eastman CG, Casavant TL, Sheffield VC: Missense variations in the fibulin 5 gene and age-related macular degeneration. $N$ Engl J Med 2004, 351:346-353.

37. Schultz DW, Klein ML, Humpert AJ, Luzier CW, Persun V, Schain M, Mahan A, Runckel C, Cassera M, Vittal V, Doyle TM, Martin TM, Weleber RG, Francis PJ, Acott TS: Analysis of the ARMD1 locus: evidence that a mutation in HEMICENTIN-1 is associated with age-related macular degeneration in a large family. Hum Mol Genet 2003, 12:3315-3323.
38. Conrad DF, Pinto D, Redon R, Feuk L, Gokcumen O, Zhang Y, Aerts J, Andrews TD, Barnes C, Campbell P, Fitzgerald T, Hu M, Ihm CH, Kristiansson K, Macarthur DG, Macdonald JR, Onyiah I, Pang AW, Robson S, Stirrups K, Valsesia A, Walter K, Wei J, Tyler-Smith C, Carter NP, Lee C, Scherer SW, Hurles ME: Origins and functional impact of copy number variation in the human genome. Nature 2010, 464:704-712.

39. The Centre for Applied Genomics: Database of genomic variants. http://projects.tcag.ca/variation.

40. Gu W, Zhang F, Lupski JR: Mechanisms for human genomic rearrangements. Pathogenetics 2008, 1:4.

41. Lupski JR, Stankiewicz P: Genomic disorders: molecular mechanisms for rearrangements and conveyed phenotypes. PLoS Genet 2005, 1:e49.

42. Fanciulli M, Petretto E, Aitman TJ: Gene copy number variation and common human disease. Clin Genet 2010, 77:201-213.

43. Zhang F, Gu W, Hurles ME, Lupski JR: Copy number variation in human health disease, and evolution. Annu Rev Genomics Hum Genet 2009, 10:451-481.

44. Liu S, Yao L, Ding D, Zhu H: CCL3L1 copy number variation and susceptibility to HIV-1 infection: a meta-analysis. PLoS One 2010, 5:e15778.

45. Ptacek T, Li X, Kelley JM, Edberg JC: Copy number variants in genetic susceptibility and severity of systemic lupus erythematosus. Cytogenet Genome Res 2008, 123:142-147.

46. Hollox EJ, Huffmeier U, Zeeuwen PL, Palla R, Lascorz J, Rodijk-Olthuis D, van de Kerkhof PC, Traupe H, de Jongh G, den Heijer M, Reis A, Armour JA, Schalkwijk J: Psoriasis is associated with increased beta-defensin genomic copy number. Nat Genet 2008, 40:23-25.

47. Hageman GS, Hancox LS, Taiber AJ, Gehrs KM, Anderson DH, Johnson LV, Radeke MJ, Kavanagh D, Richards A, Atkinson J, Meri S, Bergeron J, Zernant J, Merriam J, Gold B, Allikmets R, Dean M: Extended haplotypes in the complement factor $\mathrm{H}$ (CFH) and CFH-related (CFHR) family of genes protect against age-related macular degeneration: characterization, ethnic distribution and evolutionary implications. Ann Med 2006, 38:592-604.

48. Hughes AE, Orr N, Esfandiary H, Diaz-Torres M, Goodship T, Chakravarthy U: A common CFH haplotype with deletion of CFHR1 and CFHR3, is associated with lower risk of age-related macular degeneration. Nat Genet 2006, 38:1173-1177.

49. Fritsche LG, Lauer N, Hartmann A, Stippa S, Keilhauer CN, Oppermann M, Pandey MK, Kohl J, Zipfel PF, Weber BH, Skerka C: An imbalance of human complement regulatory proteins CFHR1 CFHR3 and factor $\mathrm{H}$ influences risk for age-related macular degeneration (AMD). Hum Mol Genet 2010, 19:4694-4704

50. Spencer KL, Hauser MA, Olson LM, Schmidt S, Scott WK, Gallins P, Agarwal A, Postel EA, Pericak-Vance MA, Haines JL: Deletion of CFHR3 and CFHR1 genes in age-related macular degeneration. Hum Mol Genet 2008, 17:971-977.

51. Schmid-Kubista KE, Tosakulwong N, Wu Y, Ryu E, Hecker LA, Baratz KH, Brown WL, Edwards AO: Contribution of copy number variation in the regulation of complement activation locus to development of age-related macular degeneration. Invest Ophthalmol Vis Sci 2009, 50:5070-5079.

52. Sawitzke J, Im KM, Kostiha B, Dean M, Gold B: Association assessment of copy number polymorphism and risk of age-related macular degeneration. Ophthalmology 2011, 118:2442-2446.

53. Sivakumaran TA, Igo RP Jr, Kidd JM, Itsara A, Kopplin LJ, Chen W, Hagstrom SA, Peachey NS, Francis PJ, Klein ML, Chew EY, Ramprasad VL, Tay WT, Mitchell P, Seielstad M, Stambolian DE, Edwards AO, Lee KE, Leontiev DV Jun G, Wang Y, Tian L, Qiu F, Henning AK, Laframboise T, Sen P, Aarthi M, George R, Raman R, Das MK, et al: A $32 \mathrm{~kb}$ critical region excluding $\mathrm{Y} 402 \mathrm{H}$ in CFH mediates risk for age-related macular degeneration. PLOS One 2011, 6:e25598.

54. Frova $C$ : Glutathione transferases in the genomics era: new insights and perspectives. Biomol Eng 2006, 23:149-169.

55. Rose-Zerilli MJ, Barton SJ, Henderson AJ, Shaheen SO, Holloway JW: Copynumber variation genotyping of GSTT1 and GSTM1 gene deletions by real-time PCR. Clin Chem 2009, 55:1680-1685.

56. Zhou J, Hu J, Guan H: The association between copy number variations in glutathione S-transferase $\mathrm{M} 1$ and $\mathrm{T} 1$ and age-related cataract in a Han Chinese population. Invest Ophthalmol Vis Sci 2010, 51:3924-3928.

57. Brasch-Andersen C, Christiansen L, Tan Q, Haagerup A, Vestbo J, Kruse TA: Possible gene dosage effect of glutathione-S-transferases on atopic asthma: using real-time PCR for quantification of GSTM1 and GSTT1 gene copy numbers. Hum Mutat 2004, 24:208-214. 
58. Oz O, Aras Ates N, Tamer L, Yildirim O, Adiguzel U: Glutathione Stransferase $\mathrm{M} 1, \mathrm{~T} 1$, and $\mathrm{P} 1$ gene polymorphism in exudative age-related macular degeneration: a preliminary report. Eur J Ophthalmol 2006, 16:105-110

59. Guven M, Gorgun E, Unal M, Yenerel M, Batar B, Kucumen B, Dinc UA, Guven GS, Ulus T, Yuksel A: Glutathione S-transferase M1, GST1 and GSTP1 genetic polymorphisms and the risk of age-related macular degeneration. Ophthalmic Res 2011, 46:31-37.

60. Kimura K, Isashiki Y, Sonoda S, Kakiuchi-Matsumoto T, Ohba N: Genetic association of manganese superoxide dismutase with exudative agerelated macular degeneration. Am J Ophthalmol 2000, 130:769-773.

61. Meyer KJ, Davis LK, Schindler El, Beck JS, Rudd DS, Grundstad AJ, Scheetz TE, Braun TA, Fingert JH, Alward WL, Kwon YH, Folk JC, Russell SR, Wassink TH, Stone EM, Sheffield VC: Genome-wide analysis of copy number variants in age-related macular degeneration. Hum Genet 2011, 129:91-100.

62. Liu MM, Agron E, Chew E, Meyerle C, Ferris FL 3rd, Chan CC, Tuo J: Copy number variations in candidate genes in neovascular age-related macular degeneration. Invest Ophthalmol Vis Sci 2011, 52:3129-3135.

63. Chan CC, Tuo J, Bojanowski CM, Csaky KG, Green WR: Detection of CX3CR1 single nucleotide polymorphism and expression on archived eyes with age-related macular degeneration. Histol Histopathol 2005, 20:857-863.

64. Costello JF, Fruhwald MC, Smiraglia DJ, Rush LJ, Robertson GP, Gao X, Wright FA, Feramisco JD, Peltomaki P, Lang JC, Schuller DE, Yu L, Bloomfield CD, Caligiuri MA, Yates A, Nishikawa R, Su Huang H, Petrelli NJ, Zhang X, O'Dorisio MS, Held WA, Cavenee WK, Plass C: Aberrant CpG-island methylation has non-random and tumour-type-specific patterns. Nat Genet 2000, 24:132-138.

65. Robertson KD: DNA methylation and human disease. Nat Rev Genet 2005, 6:597-610

66. Jirtle RL, Skinner MK: Environmental epigenomics and disease susceptibility. Nat Rev Genet 2007, 8:253-262.

67. Bollati V, Schwartz J, Wright R, Litonjua A, Tarantini L, Suh H, Sparrow D, Vokonas $\mathrm{P}$, Baccarelli A: Decline in genomic DNA methylation through aging in a cohort of elderly subjects. Mech Ageing Dev 2009, 130:234-239.

68. Age-Related Eye Disease Study Research Group: A randomized, placebocontrolled, clinical trial of high-dose supplementation with vitamins $C$ and $E$, beta carotene, and zinc for age-related macular degeneration and vision loss: AREDS report no. 8. Arch Ophthalmol 2001, 119:1417-1436.

69. Olson JH, Erie JC, Bakri SJ: Nutritional supplementation and age-related macular degeneration. Semin Ophthalmol 2011, 26:131-136.

70. Seddon JM, Reynolds R, Shah HR, Rosner B: Smoking, dietary betaine, methionine, and vitamin $d$ in monozygotic twins with discordant macular degeneration: epigenetic implications. Ophthalmology 2011 118:1386-1394.

71. Kim VN: MicroRNA biogenesis: coordinated cropping and dicing. Nat Rev Mol Cell Biol 2005, 6:376-385.

72. Lewis BP, Burge CB, Bartel DP: Conserved seed pairing, often flanked by adenosines, indicates that thousands of human genes are microRNA targets. Cell 2005, 120:15-20.

73. Garzon R, Marcucci G, Croce CM: Targeting microRNAs in cancer: rationale, strategies and challenges. Nat Rev Drug Discov 2010, 9:775-789.

74. O'Connell RM, Rao DS, Chaudhuri AA, Baltimore D: Physiological and pathological roles for microRNAs in the immune system. Nat Rev Immunol 2010, 10:111-122

75. Wang S, Koster KM, He Y, Zhou Q: miRNAs as potential therapeutic targets for age-related macular degeneration. Future Med Chem 2012, 4:277-287.

76. Lukiw WJ, Surjyadipta B, Dua P, Alexandrov PN: Common micro RNAs (miRNAs) target complement factor $\mathrm{H}(\mathrm{CFH})$ regulation in Alzheimer's disease (AD) and in age-related macular degeneration (AMD). Int $\mathrm{J}$ Biochem Mol Biol 2012, 3:105-116.

77. Kaneko H, Dridi S, Tarallo V, Gelfand BD, Fowler BJ, Cho WG, Kleinman ME, Ponicsan SL, Hauswirth WW, Chiodo VA, Kariko K, Yoo JW, Lee DK, Hadziahmetovic M, Song Y, Misra S, Chaudhuri G, Buaas FW, Braun RE, Hinton DR, Zhang Q, Grossniklaus HE, Provis JM, Madigan MC, Milam AH, Justice NL, Albuquerque RJ, Blandford AD, Bogdanovich S, Hirano Y, et al: DICER1 deficit induces Alu RNA toxicity in age-related macular degeneration. Nature 2011, 471:325-330.

78. Shen J, Yang X, Xie B, Chen Y, Swaim M, Hackett SF, Campochiaro PA MicroRNAs regulate ocular neovascularization. Mol Ther 2008, 16:1208-1216.
79. Zhou Q, Gallagher R, Ufret-Vincenty R, Li X, Olson EN, Wang S: Regulation of angiogenesis and choroidal neovascularization by members of microRNA-23 2724 clusters. Proc Natl Acad Sci U S A 2011, 108:8287-8292.

80. Lin H, Qian J, Castillo AC, Long B, Keyes KT, Chen G, Ye Y: Effect of miR-23 on oxidant-induced injury in human retinal pigment epithelium cells. Invest Ophthalmol Vis Sci 2011, 52:6308-6314.

81. Beatty $\mathrm{S}$, Koh H, Phil M, Henson D, Boulton M: The role of oxidative stress in the pathogenesis of age-related macular degeneration. Surv Ophthalmol 2000, 45:115-134.

82. Blasiak J, Szaflik JP: DNA damage and repair in age-related macular degeneration. Front Biosci 2011, 16:1291-1301.

83. Jarrett SG, Lin H, Godley BF, Boulton ME: Mitochondrial DNA damage and its potential role in retinal degeneration. Prog Retin Eye Res 2008, 27:596-607.

84. Gredilla R, Bohr VA, Stevnsner T: Mitochondrial DNA repair and association with aging-an update. Exp Gerontol 2010, 45:478-488.

85. Wang AL, Lukas TJ, Yuan M, Neufeld AH: Increased mitochondrial DNA damage and down-regulation of DNA repair enzymes in aged rodent retinal pigment epithelium and choroid. Mol Vis 2008, 14:644-651.

86. Liang FQ, Godley BF: Oxidative stress-induced mitochondrial DNA damage in human retinal pigment epithelial cells: a possible mechanism for RPE aging and age-related macular degeneration. Exp Eye Res 2003, 76:397-403.

87. Barron MJ, Johnson MA, Andrews RM, Clarke MP, Griffiths PG, Bristow E, He LP, Durham S, Turnbull DM: Mitochondrial abnormalities in ageing macular photoreceptors. Invest Ophthalmol Vis Sci 2001, 42:3016-3022.

88. Kenney MC, Atilano SR, Boyer D, Chwa M, Chak G, Chinichian S, Coskun P, Wallace DC, Nesburn AB, Udar NS: Characterization of retinal and blood mitochondrial DNA from age-related macular degeneration patients. Invest Ophthalmol Vis Sci 2010, 51:4289-4297.

89. Karunadharma PP, Nordgaard CL, Olsen TW, Ferrington DA: Mitochondrial DNA damage as a potential mechanism for age-related macular degeneration. Invest Ophthalmol Vis Sci 2010, 51:5470-5479.

90. Jones MM, Manwaring N, Wang JJ, Rochtchina E, Mitchell P, Sue CM: Mitochondrial DNA haplogroups and age-related maculopathy. Arch Ophthalmol 2007, 125:1235-1240.

91. Udar N, Atilano SR, Memarzadeh M, Boyer DS, Chwa M, Lu S, Maguen B, Langberg J, Coskun P, Wallace DC, Nesburn AB, Khatibi N, Hertzog D, Le K, Hwang D, Kenney MC: Mitochondrial DNA haplogroups associated with age-related macular degeneration. Invest Ophthalmol Vis Sci 2009. 50:2966-2974

92. Canter JA, Olson LM, Spencer K, Schnetz-Boutaud N, Anderson B, Hauser MA, Schmidt S, Postel EA, Agarwal A, Pericak-Vance MA, Sternberg P Jr, Haines JL: Mitochondrial DNA polymorphism A4917G is independently associated with age-related macular degeneration. PLoS One 2008, 3: e2091.

93. SanGiovanni JP, Arking DE, lyengar SK, Elashoff M, Clemons TE, Reed GF, Henning AK, Sivakumaran TA, Xu X, DeWan A, Agron E, Rochtchina E, Sue CM, Wang JJ, Mitchell P, Hoh J, Francis PJ, Klein ML, Chew EY, Chakravarti A: Mitochondrial DNA variants of respiratory complex I that uniquely characterize haplogroup T2 are associated with increased risk of age-related macular degeneration. PLoS One 2009, 4:e5508.

doi:10.1186/1479-7364-6-13

Cite this article as: Liu et al:: Genetic mechanisms and age-related macular degeneration: common variants, rare variants, copy number variations, epigenetics, and mitochondrial genetics. Human Genomics 2012 6:13 